\title{
Effect of Supplementation of Chelated Zinc on Milk Production in Ewes
}

\author{
Ayman Ahmed Hassan ${ }^{1 *}$, Ghada Mostafa El Ashry ${ }^{2}$, Soliman Mohamed Soliman ${ }^{2}$ \\ ${ }^{1}$ Animal Production Research Institute, Ministry of Agriculture, Dokki, Giza, Egypt; ${ }^{2}$ Regional Centre for Food Feed, Agriculture \\ Research Centre, Ministry of Agriculture, Dokki, Giza, Egypt. \\ Email: *Aymanan19@hotmail.com
}

Received January $4^{\text {th }}, 2011$; revised July $13^{\text {th }}, 2011$; accepted July $20^{\text {th }}, 2011$.

\begin{abstract}
ABSTRAC
This study was carried out at the Noubaria Station, Animal Production Research Institute. Twelve Barki ewes at 3 - 4 years of age $45 \pm 1.5 \mathrm{~kg}$ body weight were used in the present investigations. Animals were stratified for their initial body weight and age. Each group was composed of 4 pregnant animals at three months. All animals were housed in semi open pens in which water was ad-libitum. The first diet contains the basal diet plus $25 \mathrm{mg}$ of $\mathrm{Zn} / \mathrm{kg} D M$ as $\left(\mathrm{ZnSO}_{4} \cdot 7 \mathrm{H}_{2} \mathrm{O}\right.$ ). The second and the third diets contain the basal diet plus 15 and $25 \mathrm{mg}$ of $\mathrm{Zn} / \mathrm{kg} \mathrm{DM}$ as (Zn methionine, (ZnMet)) respectively. The inorganic $\mathrm{Zn}\left(\mathrm{ZnSO}_{4} \cdot 7 \mathrm{H}_{2} \mathrm{O}\right)$ caused a significant decline $(P<0.05)$ in digestibility coefficients, nutritive value, nitrogen utilization, Cell wall constituents, total VFA's, rumen volume, microbial nitrogen synthesis and milk composition and yield compared to the both organic Zn (ZnMet). While, organic Zn (ZnMet) caused a significant decline $(P<0.05)$ in glucose and urea compared to the inorganic $\mathrm{Zn}\left(\mathrm{ZnSO}_{4} \cdot 7 \mathrm{H}_{2} \mathrm{O}\right)$. But inorganic or organic zinc did not cause any effect on the serum total protein (TP), albumin (A) concentration, globulin, creatinine, aspartates aminotransferase (AST) and alanine aminotransferase (ALT). The inorganic $\mathrm{Zn}\left(\mathrm{ZnSO}_{4} \cdot 7 \mathrm{H}_{2} \mathrm{O}\right)$ caused a significant decline $(P<0.05)$ in the antioxidants activity (GSH, GSH-Px, SOD and MDA) compared to the both organic $\mathrm{Zn}(\mathrm{ZnMet})$.
\end{abstract}

Keywords: Inorganic Zn, Organic Zn, Digestibility Coefficients, Nutritive Value, Nitrogen Utilization, Milk Yield, Antioxidants Activity

\section{Introduction}

Zinc has been associated with protein in several biological systems, particularly enzymes. Several zinc metalloenzymes have been characterized [1]. Orally administered zinc appears to be absorbed at different rates by various parts of the digestive tract in dairy cattle [2]. More evidence is needed before concluding that some organs of the gastro-intestinal tract absorb and retain zinc to a greater extent than other organs. These studies in vivo and in vitro were designed to determine the uptake of zinc by the rumen tissue of lambs.

Chelation refers to a bonding formed between a metal ion (mineral) and ligand (protein or amino acid). A mineral complex is a mixture the mineral and organic compound. The biological role of chelated trace minerals is important. To be beneficial in dairy cows, the product should be stable in the rumen and digestive tract.

Zinc bioavailability from a variety of organic sources has been evaluated in numerous in vivo experiments [3].
However, a limited amount of research has compared zinc methionine (ZnMet), which is produced by chelation of ionized $\mathrm{Zn}$ from a soluble $\mathrm{Zn}$ salt with AA or partially hydrolyzed protein [4] with inorganic Zn sources. Previously, ZnMet has improved performance and carcass characteristics in feedlot steers [5] and hoof quality measurements in fattening bulls [6] and has increased $\mathrm{Zn}$ concentrations in plasma, liver, and kidney of calves supplemented with high $\mathrm{Zn}$ concentrations $(500 \mathrm{mg} / \mathrm{kg}$ of $\mathrm{DM})$ [7], relative to inorganic $\mathrm{Zn}$ sources $\left(\mathrm{ZnSO}_{4}\right.$ or $\mathrm{ZnO}$ ). Although the mechanisms responsible for these observed differences remain unclear, it has been hypothesized that $\mathrm{Zn}$ bound to organic compounds is more available for absorption than $\mathrm{Zn}$ from inorganic sources [8].

Some researchers $[9,10]$ have reported greater bioavailability for organic $\mathrm{Zn}$ sources than that observed for inorganic forms, including $\mathrm{Zn}$ oxide and $\mathrm{Zn}$ sulfate; consequently, organic forms of the element have been used with increasing frequency by the feed industry. In gen- 
eral, variable bioavailability values have been reported with the trace mineral chelates and complexes, indicating no advantage to the use of organic forms of this element [11].

The antioxidant properties of zinc were first demonstrated in vitro, there is also clear evidence that zinc functions as an antioxidant in the body. One area of growing interest is the role of zinc as an antioxidant in the central nervous system (CNS), particularly the brain. Compared to other soft tissues, the human brain contains significant amounts of zinc. Among the essential trace elements, zinc is second only to iron in total concentration in the brain. [12]

The main objective of our studies was to evaluate supplementation of different forms (inorganic vs organic) Zinc on digestibility, ruminal fermentation, milk production, biochemical parameters and antioxidant response in ewes.

\section{Materials and Methods}

\subsection{Animal and Experimental Design}

This study was carried out at the Noubaria Station, Animal Production Research Institute. Twelve Barki ewes at 3 - 4 years of age $45 \pm 1.5 \mathrm{~kg}$ body weight were used in the present investigations. Animals were stratified for their initial body weight and age. Each group was composed of 4 pregnant animals at three months. All animals were housed in semi open pens in which water was adlibitum.

\subsection{Experimental Diets}

(Table 1) shows the experimental diets fed to ewes. In this experiment, concentrate feed mixture was used, its consisted of $45 \%$ yellow corn, $31.5 \%$ wheat bran, $5 \%$ undecorticated cotton seed meal, $10 \%$ soybean meal, $5 \%$ molasses, $2 \%$ limestone, $1 \%$ salt and 0.5 premix (containing $25 \mathrm{mg} \mathrm{Zn}$ ) as basal diet. The first diet contains the basal diet plus $25 \mathrm{mg}$ of $\mathrm{Zn} / \mathrm{kg} \mathrm{DM}$ as $\left(\mathrm{ZnSO}_{4} \cdot 7 \mathrm{H}_{2} \mathrm{O}\right)$. The second and the third diets contain the basal diet plus 15 and $25 \mathrm{mg}$ of $\mathrm{Zn} / \mathrm{kg}$ DM as (Zn methionine, (ZnMet)) respectively, which was approximately around the $\mathrm{Zn}$ recommended levels of [13]. The diet was offered in two equal portions daily ( 8.00 and 16.00 ).

Kids were kept with their dams all the time except on the day of milk yield determination. The kids were separated from their dams at $7 \mathrm{p} . \mathrm{m}$. of the day perior to the recording day. Dams were milked at 7 a.m. and 5 p.m. Milk samples were collected once biweekly at $0,2,4,8$ and 10 week for recording milk yield production. A sample of milk $(100 \mathrm{ml})$ was taken from two consecutive milking. Milk samples were chemically analyzed for total solid (TS), protein, fat and ash according to [14]
Table 1. Chemical analysis of the concentrate feed mixture (CFM) and Rice straw (RS) fed to ewes (on DM basis).

\begin{tabular}{ccc}
\hline Item & CFM & RS \\
\hline DM & 88.10 & 89.68 \\
OM & 95.46 & 87.66 \\
CP & 13.75 & 3.75 \\
CF & 6.93 & 38.65 \\
EE & 2.83 & 0.89 \\
NFE & 71.95 & 44.37 \\
Ash & 4.54 & 12.34 \\
NDF & 23.27 & 73.21 \\
ADF & 11.68 & 47.54 \\
ADL & 7.44 & 21.77 \\
Hemicellulose & 11.59 & 25.67 \\
Cellulose & 4.24 & 25.77 \\
\hline
\end{tabular}

Basal diet analyzed $25 \mathrm{mg}$ of $\mathrm{Zn} / \mathrm{kg}$ of DM; Vitamin premix contained per kg: 6,600,000 IU of vitamin A, 4,400,000 I. U. of vitamin D, and 2,200 I U of vitamin E; Trace minerals provided in $\mathrm{mg} / \mathrm{kg}$ of diet: $25 \mathrm{mg}$ of $\mathrm{Fe}$ as $\mathrm{FeSO}_{4}, 20 \mathrm{mg}$ of $\mathrm{Mn}$ as $\mathrm{MnSO}_{4}, 10 \mathrm{mg}$ of $\mathrm{Cu}$ as $\mathrm{CuSO}_{4}, 0.5 \mathrm{mg}$ of I as $\mathrm{Ca}\left(\mathrm{IO}_{3}\right) \cdot \mathrm{H}_{2} \mathrm{O}, 0.1 \mathrm{mg}$ of $\mathrm{Co}$ as $\mathrm{CoCO}_{3}$, and $0.1 \mathrm{mg}$ of $\mathrm{Se}$ as $\mathrm{NaSeO}_{3}$.

while, lactose was calculated by differences.

\subsection{Blood Collection and Analysis}

Blood samples were collected at the end of experiment. Blood samples were obtained from the external jugular vein of the animals in the morning before access to feed and water. Plasma or serum were obtained by centrifugation of blood and were stored at $-20^{\circ} \mathrm{C}$ until analysis. Serum total protein (TP) was measured by the Biuret method according to [15]. Albumin (A) concentration was determined according to the method of [16] while globulin was calculated. Kidney function was evaluated by measuring blood urea using the colorimetric methods [17] using commercial kits. Creatinine was measured using the colorimetric method according to [18]. Liver function was assessed by measuring the activities of aspartates aminotransferase (AST) and alanine aminotransferase (ALT) in the serum as [19].

\subsection{Feces Collection and Analysis}

In this experiment, the same diets in trial 1 were used. Three adult male sheep Barki weighing approximately $55.50 \pm 2.00 \mathrm{~kg} \mathrm{BW}$, were housed in metabolic cages. Sheep were kept on the diets for a preliminary period of 21 days, and during the next 7-day total feces and urine were collected. Subsamples $(20 \%)$ of feces and urine were taken once daily and were frozen until analyses. Fecal samples were dried at $60^{\circ} \mathrm{C}$ for $72 \mathrm{~h}$. Feed and fecal samples were ground through $1 \mathrm{~mm}$ screen on a Wiley mill grinder and the sample $(50 \mathrm{gm} / \mathrm{sample} /$ treatment/sheep) were composed for analysis. The samples of feed and feces were analyzed for crude protein (CP), crude fiber (CF), Ether extract (EE) and ash, while the urine sample output for each sheep was analyzed for nitrogen (N) [14]. Cell wall was analyzed for neutral de- 
tergent fiber (NDF), acid detergent fiber (ADF) and acid detergent lignin (ADL) using Tecator Fibrotic system. Hemicelluloses and cellulose were determined by difference [20].

\subsection{Rumen Liquid Collection and Analysis}

Rumen liquid samples taken at 0,3 and $6 \mathrm{~h}$ post feeding from three fistulae adult female Barki sheep weighing approximately $45.50 \pm 0.50 \mathrm{~kg} \mathrm{BW}$ for each treatment, were analyzed immediately for $\mathrm{pH}$ using Orian 680 digital $\mathrm{pH}$ meter. Samples were strained through four layers of chesses cloth. For each sampling time, rumen fluid samples were preserved for ammonia nitrogen $\left(\mathrm{NH}_{3}-\mathrm{N}\right)$ determination by adding concentrated $\mathrm{H}_{2} \mathrm{SO}_{4}$ (3 drop per $5 \mathrm{ml}$ ). The concentration of $\mathrm{NH}_{3}-\mathrm{N}$ was determined by using magnesium oxide $(\mathrm{MgO})$ as [14]. Total volatile fatty acid (VFA's) concentration was estimated by using steam distillation methods [21]. Total bacteria count was carried out according to (Difco, 1984). Rumen volume was determined by the calorimetric method using $\mathrm{Cr}$ EDTA before and after, 3 and $6 \mathrm{~h}$ of feeding [22].

\subsection{Measurements of SOD, GSH and MDA Activities}

Total SOD activity was determined [23]. Glutathione peroxidase (GSH-Px) activity was measured [24]. The malondialdehyde (MDA) levels were determined by the method based on the reaction of MDA with thiobarbituric acid according to [25].

\subsection{Statistical Analysis}

Means were calculated for all variables by cow within period. Data were analyzed using the mixed procedure of SAS [26]. Period and cow were considered random effects; diet and cannulation effects were considered fixed. Estimation method was restricted maximum likelihood and the degrees of freedom method was [26]. Differences were tested using the PDIFF option in SAS [26] using a protected $(P<0.10)$ LSD test. Differences were declared significant at a $P<0.05$; and trends were discussed at a $P$ $<0.15$, unless stated otherwise.

\section{Results and Discussion}

\subsection{Digestibility Coefficients, Nutritive Values and Nitrogen Utilization}

Dry matter intake, apparent digestibility coefficients, feeding values and nitrogen utilization of inorganic or organic $\mathrm{Zn}$ rations fed to sheep were illustrated in (Table 2) Feed intake was not significantly affected by $Z n$ source or level during the experiment. [27] in the first of three experiments, feed intake tended to drop less in zinc methionine fed calves challenged with Infectious Bovine
Table 2. Dry matter intake, digestion coefficients, cell wall constituents, nutritive values and nitrogen utilization of experimental rations (mean $\pm \mathrm{SE}$ ).

\begin{tabular}{|c|c|c|c|}
\hline Item & $\begin{array}{c}25 \mathrm{mg} \mathrm{Zn} \\
\left(\mathrm{ZnSO}_{4}\right)\end{array}$ & $\begin{array}{c}15 \mathrm{mg} \mathrm{Zn} \\
\text { (ZnMet) }\end{array}$ & $\begin{array}{c}25 \mathrm{mg} \mathrm{Zn} \\
\text { (ZnMet) }\end{array}$ \\
\hline \multicolumn{4}{|c|}{ DM intake, $\mathrm{g} / \mathbf{h} / \mathbf{d}$} \\
\hline $\begin{array}{l}\text { Rice straw (RS) } \\
\text { intake, g }\end{array}$ & $402.07 \pm 27.92$ & $377.82 \pm 37.58$ & $348.26 \pm 18.18$ \\
\hline CFM intake, $g$ & $745.91 \pm 17.86$ & $746.98 \pm 8.99$ & $736.63 \pm 14.26$ \\
\hline Total DMI, g & $1147.98 \pm 32.28$ & $1124.83 \pm 29.33$ & $1085.02 \pm 26.15$ \\
\hline $\mathrm{R}: \mathrm{C}$ ratio & $35: 65$ & $34: 66$ & $32: 68$ \\
\hline \multicolumn{4}{|c|}{ Digestion coefficients (\%). } \\
\hline DM & $65.93 \pm 0.87^{\mathrm{b}}$ & $68.91 \pm 0.33^{\mathrm{a}}$ & $65.19 \pm 0.43^{b}$ \\
\hline $\mathrm{OM}$ & $66.40 \pm 0.80^{b}$ & $69.44 \pm 0.33^{\mathrm{a}}$ & $65.70 \pm 0.48^{b}$ \\
\hline $\mathrm{CP}$ & $57.45 \pm 1.00^{\mathrm{b}}$ & $61.69 \pm 0.55^{\mathrm{a}}$ & $59.71 \pm 0.18^{\mathrm{ab}}$ \\
\hline $\mathrm{CF}$ & $55.83 \pm 1.49^{\mathrm{b}}$ & $60.18 \pm 0.29^{\mathrm{a}}$ & $57.81 \pm 0.43^{\mathrm{ab}}$ \\
\hline $\mathrm{EE}$ & $73.84 \pm 3.43^{\mathrm{b}}$ & $77.79 \pm 0.78^{\mathrm{a}}$ & $73.87 \pm 0.98^{b}$ \\
\hline NFE & $70.67 \pm 0.64^{\mathrm{b}}$ & $73.03 \pm 0.27^{\mathrm{a}}$ & $68.56 \pm 0.78^{b}$ \\
\hline \multicolumn{4}{|c|}{ Nutritive values $(\%)$. } \\
\hline TDN & $63.55 \pm 0.72^{\mathrm{b}}$ & $66.63 \pm 0.53^{\mathrm{a}}$ & $63.14 \pm 0.49^{\mathrm{b}}$ \\
\hline DCP & $5.89 \pm 0.03^{b}$ & $6.45 \pm 0.19^{\mathrm{a}}$ & $6.32 \pm 0.06^{\mathrm{a}}$ \\
\hline \multicolumn{4}{|c|}{ Cell wall constituents \%. } \\
\hline NDF & $57.89 \pm 0.66^{\mathrm{c}}$ & $65.48 \pm 0.51^{\mathrm{a}}$ & $61.99 \pm 0.72^{b}$ \\
\hline $\mathrm{ADF}$ & $55.39 \pm 0.26^{\mathrm{b}}$ & $59.69 \pm 0.65^{\mathrm{a}}$ & $57.95 \pm 0.48^{\mathrm{a}}$ \\
\hline $\mathrm{ADL}$ & $45.93 \pm 0.18^{\mathrm{b}}$ & $51.88 \pm 0.33^{\mathrm{a}}$ & $49.83 \pm 0.42^{\mathrm{a}}$ \\
\hline \multicolumn{4}{|c|}{ Nitrogen utilization (g/h/d) } \\
\hline N-Intake & $18.82 \pm 0.42$ & $18.79 \pm 0.17$ & $18.38 \pm 0.36$ \\
\hline N-Absorbed (NA) & $10.82 \pm 0.35^{b}$ & $11.59 \pm 0.02^{\mathrm{a}}$ & $10.97 \pm 0.25$ \\
\hline N-Retention (NR) & $2.83 \pm 0.15^{\mathrm{c}}$ & $4.47 \pm 0.06^{\mathrm{a}}$ & $3.47 \pm 0.13^{b}$ \\
\hline NR\% of NI & $15.03 \pm 0.54^{b}$ & $23.81 \pm 0.11^{\mathrm{a}}$ & $18.86 \pm 0.43^{b}$ \\
\hline NA $\%$ of NI & $26.14 \pm 0.58^{\mathrm{c}}$ & $38.60 \pm 0.52^{\mathrm{a}}$ & $31.58 \pm 0.69^{\mathrm{b}}$ \\
\hline
\end{tabular}

a,b,c Means within rows with different superscript are significantly differ $(P<$ $0.05)$.

Rhinotracheitis (IBR) compared to $\mathrm{ZnO}$ fed calves. In the second experiment, control calves fed $30 \mathrm{ppm}$ zinc had lower $(P<0.05)$ feed intake compared to zinc methionine fed calves receiving $90 \mathrm{ppm}$ zinc, while in experiment three, recovery from depressed feed intake due to IBR fever was slower for $\mathrm{ZnO}$ fed calves compared to calves fed zinc methionine. The differences among groups were significant. The sheep fed $15 \mathrm{mg} \mathrm{Zn}$ as (ZnMet) ration showed higher $(P<0.05)$ apparent digestibility DM, OM, CP, CF, EE and NFE than those fed other rations. Some researcher corroborated each other in that each found that absorption was essentially identical for inorganic and chelated zinc, being about $40 \%$, but that the chelated form of zinc was retained better $(P<$ $0.05)$ than the inorganic form of zinc [28]. The methionine of this proteinate was only of small consequence in the rumen [29]. Chelated minerals usually cost more, per unit of metal element, than the same metal in inorganic form. Absorption of zinc is also reduced by an excess or deficiency of proteins in feed [30].

Sheep fed ZnMet ration as $15 \mathrm{mg} \mathrm{Zn}$ showed higher ( $P$ $<0.05$ ) apparent digestibility DM, OM, CP, CF, EE, NFE, NDF, ADF and nutritive values TDN and DCP than those fed other rations. These results are consistent with ZnMet being absorbed more efficiently than $\mathrm{ZnSO}_{4}$ 
when supplemented at high concentrations. Increased uptake of $\mathrm{Zn}$ from ZnMet could be explained by ZnMet interacting less than $\mathrm{ZnSO}_{4}$, with antagonists that form insoluble complexes. Alternatively, $\mathrm{Zn}$ from ZnMet may have been associated with ligands that facilitated $\mathrm{Zn}$ uptake in the duodenum. Metal ions may be absorbed as part of a metal: peptide complex, there by facilitating absorption of $\mathrm{Zn}$ via intestinal transport mechanisms distinct from inorganic $\mathrm{Zn}$ [31]. The importance of enzyme function as it relates to animal performance was illustrated by zinc depletion-repletion trials reported by [32]. Zinc was shown to have a critical role in proteolytic enzyme systems associated with muscle protein turnover. Zinc functions in the immune system through energy production, protein synthesis, stabilization of membranes against bacterial end toxins, antioxidant enzyme production, and maintenance of lymphocyte replication and antibody production [33]. Adding complexes trace minerals to the lower level of inorganic supplementation improved responses over the higher levels of inorganic trace minerals. Adding additional complexes trace minerals significantly increased both antibody titer levels and macrophage killing ability over the highest level of inorganic trace mineral supplementation [34].

Data of nitrogen balance in $25 \mathrm{mg}$ of $\mathrm{Zn} / \mathrm{kg} \mathrm{DM}$ as $\left(\mathrm{ZnSO}_{4} \cdot 7 \mathrm{H}_{2} \mathrm{O}\right)$ was the lowest $(P<0.05)$ value $(2.83 \mathrm{~g})$ while in $15 \mathrm{mg} \mathrm{Zn}$ as (ZnMet) was the highest $(4.47 \mathrm{~g}$, respectively), the mean that treatments improved nitrogen balance. There were reflected in better $(P<0.05) \mathrm{N}-$ utilization of the ration fed to sheep.It may be possible for metal ions to be transported into the intestinal mucosa as part of metal peptide complexes via mechanisms distinct from ionic $\mathrm{Zn}$ [31]. Furthermore, researchers have demonstrated the ability of ruminal and omasal tissue to effectively absorb and translocate methionine and the dipeptides carnosine and methionylglycine [35]. Solubility is critical for trace mineral absorption. To maximize uptake, chelates and other complexes should be stable in the rumen and digestive tract of animals. Chelates are stable, electrically neutral complexes, which protect trace minerals from chemical reactions during digestion that would render the mineral unavailable to the animal. When inorganic mineral compounds, typically in oxide or sulfide form, are released and ionized in the stomach's low $\mathrm{pH}$, the electrically charged forms of the minerals are able to react with other products of digestion. Complexes with naturally occurring organic ligands must form if absorption is to occur. However, the formation of insoluble, unavailable substances may also result, especially in the small intestine, when pancreatic bicarbonate restores a higher, more neutral $\mathrm{pH}$. Added minerals precomplexes with organic ligands thus are used to increase bioavailability and uptake. The chelated mineral reaches the plasma intact and separates at the site of action.

\subsection{Rumen Fluid Parameters}

Resulted of (Table 3) indicated that rumen liquor $\mathrm{pH}$ values did not significantly differ among treatments. Organic $\mathrm{Zn}$ sources tested in the present study showed different degrees of acidity. When saturated solutions were prepared in deionized $\mathrm{H}_{2} \mathrm{O}$, the $\mathrm{pH}$ of the solutions decreased. The consistency of $\mathrm{pH}$ readings can be used as one criterion to test product uniformity from batch to batch [36]. The amount of organic $\mathrm{Zn}$ that could be dissolved in deionized $\mathrm{H}_{2} \mathrm{O}$ varied form source to source in the present experiments, indicating different degrees of solubility. The $\mathrm{NH}_{3}-\mathrm{N}$ concentrations were significantly $(P<0.05)$ higher in THF and THS rations than other rations.

Sheep in the ZnMet treatments had higher $(P<0.05)$ total VFA concentrations than those in the $\mathrm{ZnSO}_{4}$. Alternatively, $\mathrm{Zn}$ from $\mathrm{ZnSO}_{4}$ may have been taken up by ruminal microorganisms to a greater extent, and this could explain the lower Ruminal soluble $\mathrm{Zn}$ concentrations in steers fed $\mathrm{ZnSO}_{4}$. Steers supplemented with $\mathrm{Zn}$ proteinate [5] or a $\mathrm{Zn}$ polysaccharide [37] also had higher ruminal soluble $\mathrm{Zn}$ concentrations than those receiving inorganic $\mathrm{Zn}$ oxide. The higher total VFA concentrations observed in steers supplemented with ZnMet or ZnGly compared to animals fed the $\mathrm{ZnSO}_{4}$ treatments could relate to a slower rate of feed Consumption or reduced rate of ruminal digestion. Extremely high concentrations (1142 mg Zn per kg) of $\mathrm{ZnSO}_{4}$ have been shown to affect ruminal protozoa numbers and degradation of feed protein [38]. High dietary concentrations (250 - $1142 \mathrm{mg} \mathrm{Zn}$ per $\mathrm{kg}$ ) of organic $\mathrm{Zn}$ have also increased molar proportion of propionate in previous studies $[38,39]$. The effect of more physiological additions of $\mathrm{Zn}$ on ruminal fermentation has received little attention.

Data of rumen volumes, rates of outflow and microbial protein synthesis are presented in (Table 3). The differences among groups were significant. The ZnMet rations

Table 3. Rumen liquor parameters, total bacteria counts and microbial nitrogen synthesis of experimental rations (mean \pm SE).

\begin{tabular}{cccc}
\hline Item & $\begin{array}{c}25 \mathrm{mg} \mathrm{Zn} \\
\left(\mathrm{ZnSO}_{4}\right)\end{array}$ & $\begin{array}{c}15 \mathrm{mg} \mathrm{Zn} \\
(\mathrm{ZnMet})\end{array}$ & $\begin{array}{c}25 \mathrm{mg} \mathrm{Zn} \\
(\mathrm{ZnMet})\end{array}$ \\
\hline $\mathrm{PH}$ & $6.67 \pm 0.12$ & $6.60 \pm 0.09$ & $6.58 \pm 0.16$ \\
$\mathrm{NH}_{3}-\mathrm{N}(\mathrm{mg} / 100 \mathrm{ml})$ & $11.63 \pm 0.42^{\mathrm{a}}$ & $9.56 \pm 0.26^{\mathrm{b}}$ & $9.45 \pm 0.17^{\mathrm{b}}$ \\
Total VFA's & $8.57 \pm 0.32^{\mathrm{b}}$ & $9.22 \pm 0.41^{\mathrm{a}}$ & $9.17 \pm 0.29^{\mathrm{a}}$ \\
(meq./100 ml) & & & \\
Rumen volumes (L) & $2.94 \pm 0.24^{\mathrm{b}}$ & $3.73 \pm 0.17^{\mathrm{a}}$ & $3.66 \pm 0.21^{\mathrm{a}}$ \\
Rates of outflow (\%hr) & $6.41 \pm 0.52^{\mathrm{a}}$ & $5.01 \pm 0.18^{\mathrm{b}}$ & $5.47 \pm 0.28^{\mathrm{b}}$ \\
$\begin{array}{c}\text { Microbial nitrogen } \\
\text { synthesis (g/h/d) }\end{array}$ & $23.66 \pm 0.48^{\mathrm{b}}$ & $31.39 \pm 0.33^{\mathrm{a}}$ & $29.65 \pm 0.17^{\mathrm{a}}$ \\
\hline
\end{tabular}

${ }_{\mathrm{a}, \mathrm{b}}$ Means within rows with different superscript are significantly differ $(P<$ $0.05)$. 
were higher $(P<0.05)$ values of rumen volumes and microbial protein synthesis than inorganic $Z n$, while the both of organic $\mathrm{Zn}$ (ZnMet) were the lower $(P<0.05)$ values of rates of outflow than inorganic $\mathrm{Zn}$. Ruminal microbial protein synthesis depends on supply of adequate amounts and type of carbohydrate $(\mathrm{CHO})$ as an energy source for the synthesis of peptide bonds [40]. Synthetic amino acids or amino acids precursor (Methyl Hydroxy Analogue: MHA) are also used as ligands in chelating trace minerals. The definitive advantage of MHA is that its is non-degraded in rumen as there is no Nitrogen atom in its chemical structure and hence rumen microbes do not recognize it as a source for microbial protein synthesis escapes the rumen degradation. Moreover, the molecular size of MHA chelated is below 400 Dalton which facilitated its efficient absorption through intestine.

\subsection{Milk Yields and Milk Composition}

Data concerning milk yield and its composition are presented in (Table 4). The milk yield and fat corrected milk $(\mathrm{FCM})$ were significantly increased $(P<0.05)$ for both the $\mathrm{ZnMet}$ rations compared with inorganic $\mathrm{Zn}$ ration. The average daily milk yield were increased by $12.32 \%$ and $9.78 \%$ in $15 \mathrm{mg} \mathrm{Zn} \mathrm{(ZnMet)} \mathrm{ration} \mathrm{and} 25$ $\mathrm{mg} \mathrm{Zn} \mathrm{(ZnMet)} \mathrm{ration} \mathrm{than} 25 \mathrm{mg} \mathrm{Zn}\left(\mathrm{ZnSO}_{4}\right)$ ration, respectively. However, improving of nutrients composition, its digestibility and the feeding values of both the ZnMet rations were reflect on the more \% FCM produced by ewes fed that ration which had about $24.20 \%$ and $21.11 \%$ more $4 \% \mathrm{FCM}$ than the inorganic $\mathrm{Zn}$ ration. In addition to about $26.06 \%$ and $31.33 \%$ more protein and fat produced, respectively. This agrees with the results of [41-42]. Zinc supplement had positive influence on ewe milk production [41]. Similar results have been reported previously when dairy cows were supplemented with chelated minerals [42]. But contrast to the results [2,

Table 4. Milk yields and milk composition of lactating ewes fed on experimental rations (mean $\pm \mathrm{SE}$ ).

\begin{tabular}{cccc}
\hline Item & $\begin{array}{c}25 \mathrm{mg} \mathrm{Zn} \\
\left(\mathrm{ZnSO}_{4}\right)\end{array}$ & $\begin{array}{c}15 \mathrm{mg} \mathrm{Zn} \\
(\mathrm{ZnMet})\end{array}$ & $\begin{array}{c}25 \mathrm{mg} \mathrm{Zn} \\
(\mathrm{ZnMet})\end{array}$ \\
\hline Milk yields, g/d $^{4}$ & $431.56 \pm 21.44^{\mathrm{b}}$ & $484.73 \pm 15.72^{\mathrm{a}}$ & $473.75 \pm 11.06^{\mathrm{a}}$ \\
$4 \% \mathrm{FCM}^{*}$ & $515.52 \pm 11.65^{\mathrm{b}}$ & $640.29 \pm 20.18^{\mathrm{a}}$ & $624.35 \pm 17.62^{\mathrm{a}}$ \\
Fat, g/d & $22.66 \pm 0.26^{\mathrm{b}}$ & $29.76 \pm 0.17^{\mathrm{a}}$ & $28.99 \pm 0.29^{\mathrm{a}}$ \\
Protein, g/d & $20.11 \pm 0.33^{\mathrm{b}}$ & $25.35 \pm 0.13^{\mathrm{a}}$ & $25.16 \pm 0.12^{\mathrm{a}}$ \\
\multicolumn{4}{c}{ Milk composition (\%). } \\
Total solids & $15.24 \pm 0.42$ & $15.11 \pm 0.23$ & $15.26 \pm 0.33$ \\
Solids not fat & $9.99 \pm 0.29^{\mathrm{a}}$ & $8.97 \pm 0.31^{\mathrm{b}}$ & $9.14 \pm 0.18^{\mathrm{ab}}$ \\
Fat & $5.25 \pm 0.13^{\mathrm{b}}$ & $6.14 \pm 0.09^{\mathrm{a}}$ & $6.12 \pm 0.11^{\mathrm{a}}$ \\
Protein & $4.66 \pm 0.23^{\mathrm{b}}$ & $5.23 \pm 0.11^{\mathrm{a}}$ & $5.31 \pm 0.07^{\mathrm{a}}$ \\
Lactose & $4.29 \pm 0.27^{\mathrm{a}}$ & $2.77 \pm 0.13^{\mathrm{b}}$ & $2.86 \pm 0.18^{\mathrm{b}}$ \\
Ash & $1.04 \pm 0.02$ & $0.97 \pm 0.01$ & $0.97 \pm 0.02$ \\
\hline
\end{tabular}

${ }^{\mathrm{a}, \mathrm{b}}$ Means within rows with different superscript are significantly differ $(P<$ $0.05) ;{ }^{*} 4 \%$ FCM was calculated as: $0.4 \times$ milk yield $(\mathrm{kg})+15 \times$ fat yield (kg) Overmann and Fanmann, 1926.
$43,44]$, reported no increase in milk yield from feeding organic trace mineral complexes.

\subsection{Blood Biochemical and Serum Constituents}

The average values of some blood constituents in the blood of ewes consuming the different experimental rations are presented in (Table 5). No significant differences were observed among groups concerning the entire blood constituent. Moreover, they were within the normal average as described by [45]. [46] reported that $\mathrm{Zn}$ plays a clear role in the synthesis, storage and secretion of insulin in human as well as conformational integrity of insulin in the hexameric form. Glucagon led to a pronounced decrease in cytosolic $\mathrm{Zn}^{2+}$. Glucagon and $\mathrm{Zn}$ stimulated glycogenolysis by increasing the phosphorylation of glycogen phosphorylase but acted oppositely on glycolysis. $\mathrm{Zn}$ overcame the inactivation of pyruvate kinase by glucagon without changing the hormone-induced protein phosphorylation [47,48]. Zinc inhibits the accumulation of glucose in rat intestinal segments in vitro [48]. The uptake of glucose by brush border membrane vesicles from pig small intestinal [49].

\subsection{Antioxidant Enzyme Activities}

Data of antioxidants activity in blood of lactating ewes during experimental period were showed in (Table 6). The activity of GSH, GSH-Px, SOD and MDA increased gradually with the ZnMet. Results of isoenzyme patterns suggested that at least four isoenzyme bands are detected

Table 5. Blood serum parameters of lactating cows fed experimental ration (mean $\pm \mathrm{SE}$ ).

\begin{tabular}{cccc}
\hline Item & $\begin{array}{c}25 \mathrm{mg} \mathrm{Zn} \\
\left(\mathrm{ZnSO}_{4}\right)\end{array}$ & $\begin{array}{c}15 \mathrm{mg} \mathrm{Zn} \\
(\mathrm{ZnMet})\end{array}$ & $\begin{array}{c}25 \mathrm{mg} \mathrm{Zn} \\
(\mathrm{ZnMet})\end{array}$ \\
\hline Glucose $\mathrm{mg} / \mathrm{dl}$ & $82.79 \pm 6.34$ & $80.77 \pm 3.41$ & $81.53 \pm 4.66$ \\
Cholesterol mg/dl & $93.75 \pm 2.74$ & $92.55 \pm 0.65$ & $92.79 \pm 0.85$ \\
TP g/dl & $8.12 \pm 0.43$ & $8.25 \pm 0.22$ & $8.05 \pm 0.31$ \\
Albumin g/dl & $3.67 \pm 0.11^{\mathrm{a}}$ & $3.83 \pm 0.18^{\mathrm{a}}$ & $3.33 \pm 0.09^{\mathrm{b}}$ \\
Globulin g/dl & $4.45 \pm 0.16$ & $4.42 \pm 0.11$ & $4.72 \pm 0.15$ \\
Urea mg/dl & $40.65 \pm 0.37^{\mathrm{a}}$ & $37.65 \pm 0.55^{\mathrm{b}}$ & $36.76 \pm 0.24^{\mathrm{b}}$ \\
Creatinine, mg/dl & $0.94 \pm 0.04$ & $0.93 \pm 0.07$ & $0.94 \pm 0.03$ \\
AST U/L & $36.77 \pm 0.38$ & $37.76 \pm 0.22$ & $36.94 \pm 0.21$ \\
ALT U/L & $20.66 \pm 0.18$ & $19.86 \pm 0.14$ & $19.54 \pm 0.19$ \\
\hline
\end{tabular}

${ }^{\mathrm{a}, \mathrm{b}}$ Means within rows with different superscript are significantly differ $(P<$ $0.05)$.

Table 6. Antioxidants content in blood of lactating ewes during experimental period (mean $\pm \mathrm{SE}$ ).

\begin{tabular}{cccc}
\hline Items & $\begin{array}{c}25 \mathrm{mg} \mathrm{Zn} \\
\left(\mathrm{ZnSO}_{4}\right)\end{array}$ & $\begin{array}{c}15 \mathrm{mg} \mathrm{Zn} \\
(\mathrm{ZnMet})\end{array}$ & $\begin{array}{c}25 \mathrm{mg} \mathrm{Zn} \\
(\mathrm{ZnMet})\end{array}$ \\
\hline GSH $(\mathrm{mg} / \mathrm{dl})$ & $24.33 \pm 0.57^{\mathrm{b}}$ & $27.89 \pm 0.52^{\mathrm{a}}$ & $27.28 \pm 0.95^{\mathrm{a}}$ \\
$\mathrm{GSH}-\mathrm{Px}(\mu / \mathrm{g} \mathrm{Hb})$ & $69.328 \pm 1.57^{\mathrm{b}}$ & $75.55 \pm 1.44^{\mathrm{a}}$ & $74.77 \pm 0.86^{\mathrm{a}}$ \\
$\mathrm{SOD}(\mu / \mathrm{ml})$ & $25.74 \pm 0.46^{\mathrm{b}}$ & $28.95 \pm 0.55^{\mathrm{a}}$ & $27.43 \pm 0.34^{\mathrm{a}}$ \\
$\mathrm{MDA}(\mu \mathrm{mol} / \mathrm{ml})$ & $2.13 \pm 0.06^{\mathrm{b}}$ & $2.66 \pm 0.08^{\mathrm{a}}$ & $2.42 \pm 0.05^{\mathrm{a}}$ \\
\hline
\end{tabular}

${ }^{\mathrm{a}, \mathrm{b}}$ Means within rows with different superscript are significantly differ $(P<$ $0.05)$. 
and a novel isoenzyme is found in the cotyledons (III), hypocotyls (III) and radicles (II) at the $15 \mathrm{mg} \mathrm{Zn}$ as ZnMet. These isoenzymes show different staining intensity with the ZnMet and the staining densities of SOD isoenzyme were consistent with the changes of the activities assayed in solutions. SOD play an important role in detoxification processes by catalyzing the conversion of free $\mathrm{O}_{2}^{-}$to $\mathrm{O}_{2}$ and $\mathrm{H}_{2} \mathrm{O}_{2}$ and is associated with stress situations including zinc stress [50]. The mechanism of reactions catalyzed by SOD consists in the reduction and oxidation of metal ions which are present in the active centre of this enzyme $(\mathrm{Zn}, \mathrm{Cu})$. As a result of these reactions, hydrogen peroxide $\left(\mathrm{H}_{2} \mathrm{O}_{2}\right)$ is produced. The biosynthesis of SOD is under close control. Unfortunately, so far this process has been described only for bacterial cells [51]. But it is known that the inductor of the synthesis is a product of molecular oxygen $\left(\mathrm{O}_{2}\right)$ reduction and that this process is regulated by iron ions. It has been noted that the level of iron ions in the serum increases in conditions of exposure to lead. Even a small increase in the concentration of iron ions leads to a sudden production of reactive oxygen species (ROS), for example in the Fenton-like reaction [52]. The mechanism of catalysis influenced by SOD suggests that this enzyme is an incomplete antioxidant which protects from the action of one free oxygen radical $\mathrm{O}_{2}$. Biologically the action of SOD through $\mathrm{H}_{2} \mathrm{O}_{2}$ is connected with the action of CAT. The function of CAT is removal of $\mathrm{H}_{2} \mathrm{O}_{2}$ formed as a result of the action of the oxygen dehydrogenates. Available literature data have shown that $\mathrm{H}_{2} \mathrm{O}_{2}$ inhibits the activity of SOD, while $\mathrm{O}_{2}$ inhibits the action of CAT (Kulikowska-Karpińska and Moniuszko-Jakoniuk, 2001). In plants, environmental adversity often leads to the increased generation of reduced oxygen species and consequently, SOD has been proposed to be important in plant stress tolerance [12]. In the present study, SOD activity in the cotyledons are significant higher than those of the hypocotyls and radicles at the same zinc level, suggesting that the cotyledons are most sensitive, when exposed to zinc toxicity. Isoform enzymes of Page analysis showed that the levels of SOD transcripts are induced in response to zinc stress; however, they differ in different tissues and zinc concentrations. These results might suggest that a hierarchy of regulatory events act at the transcription of SOD genes. Pioneer studies had shown a general stimulation of constitutive SODs and the induction of specific SOD isoenzymes in different plant species (Prasad et al., 1999). Enhanced SOD activity could potentially increase oxidative stress due to increased production of $\mathrm{H}_{2} \mathrm{O}_{2}$. Based on the above results, the increased SOD activities and their isoenzymes may play an important role in the defensive mechanisms of plant seedling against zinc toxicity. POD, along with
SOD and CAT, are redox metalloenzymes involved in cell defense against oxidative stress. Plant PODs, which are encoded by small or large multigenic families, are involved in several important physiological and developmental processes [53]. POD can also be considered useful markers for environmental stresses since their activity is affected by heavy metal, salt and other environment conditions.

\section{REFERENCES}

[1] B. L. Vallce, "Biochemistry, Physiology and Pathology of Zinc," Physiological Reviews, Vol. 39, No. 3, 1959, pp. 443-490.

[2] J. K. Millerand and R. G. Cragle, "Gastrointestinal Sites of Absorption and Endogenous Secretion of Zinc in Dairy Cattle," Journal of Dairy Science, Vol. 48, No. 3, 1965, pp. 370- 373. doi: $10.3168 / \mathrm{jds} . S 0022-0302(65) 88231-5$

[3] J. W. Spears, "Organic Trace Minerals in Ruminant Nutrition," Animal Feed Science and Technology, Vol. 58, No. 1-2, 1996, pp. 151-163. doi:10.1016/0377-8401(95)00881-0

[4] Association of American Feed Control Officials, "Official Publication," Oxford, 2000.

[5] J. W. Spears and E. B. Kegley, "Effect of Zinc Source (Zinc Oxide vs Zinc Proteinate) and Level on Performance, Carcass Characteristics, and Immune Response of Growing and Finishing Steers," Journal of Animal Science, Vol. 80, No. 10, 2002, pp. 2747-2752.

[6] J. Kessler, I. Morel, P. A. Dufey, A. Gutzwiller, A. Stern and H. Geyer, "Effect of Organic Zinc Sources on Performance, Zinc Status and Carcass Meat and Claw Quality in Fattening Bulls," Livestock Production Science, Vol. 81 , No. 2, 2003, pp. 161-171. doi:10.1016/S0301-6226(02)00262-2

[7] C. L. Wrightand and J. W. Spears, "Effect of Zinc Source and Dietary Level on Zinc Metabolism in Holstein Calves," Journal of Dairy Science, Vol. 87, No. 4, 2004, pp. $1085-1091$.

doi:10.3168/jds.S0022-0302(04)73254-3

[8] C. L. Wright, J. W. Spears and K. E. Webb, "Uptake of Zinc from Zinc Sulfate and Zinc Proteinate by Ovine Ruminal and Omasal Epithelia," Journal of Animal Science, Vol. 86, No. 6, 2008, pp. 1357-1363. doi: $10.2527 /$ jas.2006-650

[9] J. W. Spears, "Zinc Methionine for Ruminants: Relative Bioavailability of Zinc in Lambs and Effects of Growth and Performance of Growing Heifers," Journal of Animal Science, Vol. 67, No. 3, 1989, pp. 835-843.

[10] K. J. Wedekind, A. E. Hortin and D. H. Baker, "Methodology for Assessing Zinc Bioavailability: Efficacy Estimates for Zinc-Methionine, Zinc Sulfate, and Zinc Oxide. Journal of Animal Science, Vol. 70, No. 1, 1992, pp. 178187.

[11] A. C. B. mmerman, D. H. Baker and A. J. Lewis, "Bioavailability of Nutrients for Animals: Amino Acids, 
Minerals, and Vitamins," Academic Press, San Diego, CA, 1995.

[12] R. Mittler, S. Vanderauwera, M. Gollary and F. van Breusegem, "Reactive Oxygen Gene Network of Plants," Trends in Plant Science, Vol. 9, No. 10, 2004, pp. 490-498.

doi:10.1016/j.tplants.2004.08.009

[13] NRC, "Nutrient Requirements of Sheep," Sixth Revised Edition, National Academy Press, Washington, DC, 1985, pp. $45-53$.

[14] AOAC, "Official Methods of Analysis," 15th Edition, Association of Analytical Chemists, Washington, DC, 1990.

[15] J. B. Henry and S. D. Todd, "Clinical Diagnosis and Measurement by Laboratory Methods," 16th Edition, W. B. Saunders, Phliadephia, 1974, p. 260.

[16] B. T. Doumas, W. A. Waston and H. G. Biggs, "Albumin Standards and the Measurements of Serum Albumin with Bromocresol Green," Clinica Chimica Acta, Vol. 31, No. 1, 1977, pp. 87-96. doi:10.1016/0009-8981(71)90365-2

[17] W. R. Faulkner and J. W. King, "Fundamentals of Clinical Chemistry," 2nd Edition, Saunders, Philadelphia, 1976, pp. 994-998.

[18] S. Reitman and S. A. Frankel, "Colorimetric Method of Determination of Serum Glutamic Oxaloacetic and Glutamic Pyrovic Transaminase," American Journal of Clinical Pathology, Vol. 28, 1957, pp. 56-63.

[19] A. C. I. Warner, "Production of Volatile Fatty Acids in the Rumen Methods of Measurement," Nutrition Abstracts \& Reviews, Vol. 34, 1964, pp. 339-352.

[20] P. J. van Soest, J. B. Robertson and B. A. Lewis, "Methods for Dietary Fiber, Neutral Detergent Fiber, and Nonstarch Polysaccharides in Relation to Animal Nutrition," Journal of Dairy Science, Vol. 74, No. 10, 1991, pp. 3583-3597. doi:10.3168/jds.S0022-0302(91)78551-2

[21] M. Difco, "Dehydrated Culture Media Reagents for Microbiology," 10th Edition, Difco Laboratories Incorporated Detroit, Michigan, 1984, p. 689.

[22] K. H. El-Shazly, A. Ahmed, M. A. Naga and B. E. A. Borhami, "A Colorimetric Techniqe Using Chromium Ethylene Diamine Tetraacetate for Measuring Rumen Volume," The Journal of Agricultural Science, Vol. 87, No. 2, 1976, pp. 369-373. doi:10.1017/S0021859600027672

[23] Y. Sun, L. W. Oberley and L. Ying, "A Simple Method for Clinical Assay of Superoxide Dismutase," Clinical Chemistry, Vol. 34, No. 3, 1988, pp. 497-500.

[24] D. E. Paglia and W. N. Valentine, "Studies on the Quantitative and Qualitative Characterization of Erythrocyte Glutathione Peroxidase," Journal of Laboratory and Clinical Medicine, Vol. 70, 1967, pp. 158-170.

[25] H. Esterbauer and K. H. Cheeseman, "Determination of Aldehydic Lipid Peroxidation Products: Malonaldehyde and 4-Hydroxynonenal," Methods Enzymol, Vol. 186, 1990, pp. 407-421. doi:10.1016/0076-6879(90)86134-H
[26] SAS Institute Inc., "SAS User's Guide," SAS Institute Inc., Cary, NC, 1999.

[27] N. K. Chirase, D. P. Hutchenson and G. B. Thompson, "Feed Intake, Rectal Temperature, and Serum Mineral Concentration of Feedlot Cattle Fed Zinc Oxide or Zinc Methionine and Challenged with IBR Virus," Journal of Animal Science, Vol. 69, 1991, pp. 4137-4145.

[28] G. P. Lardy, M. S. Kerley and J. A. Paterson, "Retention of Chelated Metal Proteinates by Lambs," Journal of Animal Science, Vol. 70, 1992, p. 314.

[29] A. J. Heinricks and H. R. Conrad, "Rumen Solubility and Breakdown Products of Metal Proteinate Compounds," Journal of Dairy Science, Vol. 66, 1983, p. 147.

[30] L. Vrzgula, A. A. Alijev, W. Barej, P. Bartko, J. Bouda, R. Dvořák and P. Garbašanski, "Disorders of Substance Metabolism of Farm Animals and Prevention Thereof (in Slovak)," 2nd Edition, Bratislava, Príroda, 1990, p. 503

[31] H. D. Ashmead, D. J. Graff and H. H. Ashmead, "A Secondary Intestinal Pathway for Absorption of DipeptideLike Amino Acid Chelates," Spring field, IL, 1985, pp. 113-123

[32] T. E. Engle, C. F. Nockels, C. V. Kimberling, D. L. Weaber and A. B. Johnson, "Zinc Repletion with Organic or Inorganic Forms of Zinc and Protein Turnover in Marginally Zinc-Deficient Calves," Journal of Animal Science, Vol. 75, 1998, pp. 3074-3081.

[33] C. F. Nockels, "Micornutrients and the Immune Response," Montana Nutrition Conference Proceedings, Bozeman, Montana, 1994, 3.1.

[34] M. T. Kidd, P. R. Ferket and M. A. Qureshi, "Zinc Metabolism with Special Reference to Its Role in Immunity," World's Poultry Science Journal, Vol. 52, 1996, pp. 309-324. doi:10.1079/WPS19960022

[35] J. C. Matthews and K. E. Webb Jr, "Absorption of L-Carnosine, L-Methionine, and L-Methionylglycine by Isolated Sheep Ruminal and Omasal Epithelium,” Journal of Animal Science, Vol. 73, 1995, pp. 3464-3475.

[36] F. T. Gressley, "Zinc, Copper, Manganese, and Selenium in Dairy Cattle Rations," Proceedings of the 7th Annual Mid-Atlantic Nutrition Conference, University of Maryland, College Park, 2009.

[37] K. D. Wennedy, W. M. Craig and L. L. Southern, "Ruminal Distribution of Zinc in Steers Fed a Polysaccharide-Zinc Complex or Zinc Oxide," Journal of Animal Science, Vol. 71, No. 5, 1993, pp. 1281-1287.

[38] M. A. Froetschel, A. C. Martin, H. E. Amos and J. J. Evans, "Effects of Zinc Sulfate Concentration and Feeding Frequency on Ruminal Protozoal Numbers, Fermentation Patterns and Amino Acid Passage in Steers," Journal of Animal Science, Vol. 68, No. 9, 1990, pp. 2874-2884.

[39] H. M. Arelovich, F. N. Owens, G. W. Horn and J. A. Vizcarra, "Effects of Supplemental Zinc and Manganese on Ruminal Fermentation, Forage Intake, and Digestibility by Cattle Fed Prairie Hay and Urea," Journal of Animal Science, Vol. 78, No. 11, 2000, pp. 2972-2979.

[40] A. Bach, S. Calsamiglia and M. D. Stern, "Nitrogen Me- 
tabolism in the Rumen," Journal of Dairy Science, Vol. 88, 2005, pp. E9-E21.

doi:10.3168/jds.S0022-0302(05)73133-7

[41] P. G. Hatfield, G. D. Snowder, W. A. J. Head, H. A. Glimp, R. H. Stobart and T. Besser, "Production by Ewes Rearing Single or Twin Lambs: Effects of Dietary Crude Protein Percentage and Supplemental Zinc Methionine," Journal of Animal Science, Vol. 73, No. 5, 1995, pp. 1227-1238.

[42] A. Formigoni, P. Parisini and F. Corradi, "The Use of Amino Acid Chelates in High Production Milk Cows," In H. D. Ashmead, Ed., The Roles of Amino Acid Chelates in Animal Nutrition, Noyes, Park Ridge, NJ, 1993, pp. 170-186.

[43] P. G. Hatfield, C. K. Swenson, R. W. Kott, R. P. Ansotegui, N. J. Roth and B. L. Robinson, "Zinc and Copper Status in Ewes Supplemented with Sulfate- and Amino acid-Complexed Forms of Zinc and Copper," Journal of Animal Science, Vol. 79, No. 1, 2001, pp. 261-266.

[44] M. H. Campbell, J. K. M. iller and F. N. Schrick, "Effect of Additional Cobalt, Copper, Manganese and Zinc on Reproduction and Milk Yield of Lacting Dairy Cows Receiving Bovine Somatotropin," Journal of Dairy Science, Vol. 82, No. 5, 1999, pp. 1019-1025. doi:10.3168/jds.S0022-0302(99)75322-1

[45] M. S. Stanek, W. FlorekRydzik and I. Rusiecka, "Effect of Energy Feeds in Diets for Sheep on Nutrient Digestibility and Rumen Digestion Process," Acta Academiae Agriculture ac Technicae Olstenesis, Zootechnica, Vol. 37, 1992, pp. 3-11.

[46] A. B. Chausmer, "Zinc, Insulin and Diabetes," Journal of the American College of Nutrition, Vol. 17, No. 2, pp. 109-115.

[47] L. A. Brand and J. Kleineke, "Intracellular Zinc Movement and Its Effect on the Carbohydrate Metabolism of Isolated Rat Hepatocytes," Journal of Biological Chemistry, Vol. 271, No. 4, 1996, pp. 1941-1949. doi:10.1074/jbc.271.4.1941

[48] V. Lyall, R. Nath and A. Mahmood, "Inhibition of DGlucose Uptake by Zinc in Rat Intestine," Biochemical Medicine, Vol. 22, No. 2, 1979, pp. 192-197. doi:10.1016/0006-2944(79)90005-X

[49] D. W. Watkins, C. Chenu and P. Ripoche, "Zinc Inhibition of Glucose Uptake in Brush-Border Membrane Vesiches from Pig Small Intestine," Archiv European Journal of Physiology, Vol. 415, No. 2, 1989, pp. 165-171. doi:10.1007/BF00370588

[50] R. J. Henry, D. C. Cannon and J. W. Winkelman, "Clinical Chemistry: Princeples and Techniques," 11 th Edition, Happer and Row Publishers, 1974, p. 1629.

[51] A. E. Liczmanska and T. Toksycznosc, "Mechanizmy Obronne," Postepy Biochemii, Vol. 4, 1988, p. 293.

[52] E. Kulikowska-Karpińska and J. Moniuszko-Jakoniuk, "Lead and Zinc Influence on Antioxidant Enzyme Activity and Malondialdehyde Concentrations," Polish Journal of Environmental Studies, Vol. 10, No. 3, 2001, pp. 161165.

[53] P. G. Hatfield, G. D. Snowder and H. A. Glimp, "The Effects of Chelated Zinc Methionine on Feedlot Lamb Performance, Cost of Gain, and Carcass Characteristics," Sheep \& Goat Research Journal, Vol. 8, 1992, pp. 1-4. 